G.V. Bezprozvannych, I.A. Kostiukov, O.A. Pushkar

\title{
SYNTHESIS OF CONSTRUCTIVE-TECHNOLOGICAL DECISIONS OF REGULATION OF WORKING CAPACITANCE OF CABLES OF INDUSTRIAL NETWORKS
} Introduction. Over the past 10 years, the number of industrial networks has more than doubled. At the physical level, all
industrial technology networks are based on twisted pair. Purpose. Synthesis of constructive-technological decisions of
regulation of electric capacitance of the insulated conductor at a stage of manufacturing of twisted pair of cables of industrial
networks. Methodology. The method of secondary charges to determine the capacitance of the insulated conductor by varying the
thickness of the solid and foamed polyethylene insulation. Practical value. Effective regulation is provided on the basis of the
obtained dependencies of the effective dielectric constant, the tangent of the dielectric loss angle and the capacitance of the
insulated conductor on the degree of foaming and the thickness of the protective film of two-layer insulation. At a degree of
porosity of $40 \%$, the dielectric constant decreases by $25 \%$, the tangent of the dielectric loss angle-by $33 \%$, the electrical
capacitance of the insulated conductor - by $20 \%$. References 18 , tables 3 , figures 5 .

Key words: industrial networks, twisted pair, insulated conductor, foaming, insulation thickness, effective dielectric constant, electrical capacitance.

Доведено більшу чутливість регулювання технологічного процесу виготовлення ізольованого провідника витої пари при охолодженні у воді в порівнянні з повітряним. При зміненні товщини ізоляції в 4 рази електрична ємність ізольованого провідника змінюється більше, ніж в 2 рази, та на 5 \% при знаходженні у воді та повітрі відповідно. Ефективне регулювання забезпечується на підставі отриманих залежностей ефективної діелектричної проникності, тангенсу кута діелектричних втрат та ємності ізольованого провідника від ступеню спінення та товщини захисної плівки двощарової ізоляиіі. При ступені пористості 40 \% діелектрична проникність зменшується на 25 \%, тангенс кута діелектричних втрат - на $33 \%$, електрична ємність ізольованого провідника - на $20 \%$ Бібл. 18, табл. 3. рис. 5.

Ключові слова: промислові мережі, вита пара, ізольований провідник, спінення, товщина ізоляції, ефективна діелектрична проникність, електрична смність.

Доказано больиую чувствительность регулирования технологического процесса изготовления изолированного проводника витой пары при охлаждении в воде по сравнению с воздушным. При изменении толщины изоляции в 4 раза электрическая емкость изолированного проводника меняется более чем в 2 раза, и на $5 \%$ при нахождении в воде и воздухе соответственно. Эффективное регулирование обеспечивается на основании полученных зависимостей эффективной диэлектрической проницаемости, тангенса угла диэлектрических потерь и емкости изолированного проводника от степени вспенивания и толщины защуитной пленки двухслойной изоляции. При степени пористости 40 \% диэлектрическая проницаемость уменьшается на $25 \%$, тангенс угла диэлектрических потерь - на 33 \%, электрическая емкость изолированного проводника - на $20 \%$ Библ. 18, табл. 3, рис. 5.

Ключевые слова: промышленные сети, витая пара, изолированный проводник, вспенивание, толшина изоляции, эффективная диэлектрическая проницаемость, электрическая емкость.

Introduction. The rapid growth of digital technologies has prompted cable manufacturers in Ukraine to introduce new technologies and types of cables, in particular, based on twisted pairs of different categories, with an appropriate set of transmission parameters, both for structured cable systems and for security systems - video surveillance, fire and security alarm system [1-6]. At the same time, each industrial enterprise to ensure the competitiveness of manufactured products contributes to the automation of both individual technological processes and production as a whole. For this purpose it is necessary to enter all active and passive devices into a single information industrial-technological network, where the interaction between the devices takes place using software-logical communication protocols. Industrial networks usually do not go beyond a single enterprise. Over the past 10 years, the number of industrial networks has more than doubled [7]. By 2025, it is expected to grow by $280 \%$ compared to 2010 [7]. At the physical level, all industrial-technological networks (FieldBus Profibus, LonWorks and others) are based on twisted pair or optical fiber, and solutions based on electrical cables are used to a greater extent (Table 1) $[3,4,7]$.
Table 1

Characteristics of industrial networks

\begin{tabular}{|c|c|c|}
\hline $\begin{array}{c}\text { Type of industrial } \\
\text { bus topology network }\end{array}$ & $\begin{array}{c}\text { Signal } \\
\text { transmission } \\
\text { speed }\end{array}$ & $\begin{array}{c}\text { Maximum signal } \\
\text { transmission range, } \mathrm{m}\end{array}$ \\
\hline Profibus DP & $\begin{array}{c}9.6 \mathrm{kBit} / \mathrm{s}- \\
12 \mathrm{kBit} / \mathrm{s}\end{array}$ & $100-1200$ \\
\hline Profibus PA & $31.25 \mathrm{kBit} / \mathrm{s}$ & 1900 \\
\hline Canopen & $\begin{array}{c}62.5 \mathrm{kBit} / \mathrm{s}- \\
1 \mathrm{MBit} / \mathrm{s}\end{array}$ & $30-1000$ \\
\hline DEviceNet & $125-500 \mathrm{kBit} / \mathrm{s}$ & $100-500$ \\
\hline
\end{tabular}

With the advent of Ethernet and the Internet for industrial networks they began to apply the same classification as for information, structured, local area networks (Table 2). The industrial Ethernet market is growing at a rate of $51 \%$ per year [7]. As the network is modernized, which involves the transition from obsolete fieldbus to Industrial Ethernet, communication cable infrastructure becomes the basis for connection to the communications of the industrial enterprise.

Existing Industrial Ethernet physical level technologies have a limit on the distance to which the signal is transmitted - no more than $100 \mathrm{~m}$.

(C) G.V. Bezprozvannych, I.A. Kostiukov, O.A. Pushkar 
Due to the fact that process automation applications require distances of $1 \mathrm{~km}$ and even more in combination with reliable field devices suitable for use in zone 0 applications (intrinsically safe), a new approach to the implementation of Ethernet physical level technology was needed. Adopted new standard 10BASE-T1L of physical level of Industrial Ethernet (IEEE 802.3cg-2019 (Table 2)) will radically change the field of process automation by significantly increasing the operational efficiency of the enterprise by organizing a highly reliable seamless (without the use of gateways) connection to Ethernet at the field level, which provides a variety of devices, including sensors and actuating mechanisms - actuators, programmable logic controllers [7]. The 10BASE-T1L Standard solves the problems that currently limit the use of Ethernet in the field in the area of process automation: insufficient bandwidth, relative complexity of cabling, limited data transmission range, which is directly related to cable bandwidth (constructive-technological solutions).

Table 2

International Standards and categories of twisted pair cables for Industrial Ethernet networks [7]

\begin{tabular}{|c|c|c|c|c|c|c|c|}
\hline $\begin{array}{l}\text { Year of } \\
\text { adoption } \\
\text { of the } \\
\text { Standard }\end{array}$ & \multicolumn{2}{|c|}{ IEEE 802.3 Standard } & $\begin{array}{l}\text { Maximum } \\
\text { signal } \\
\text { transmission } \\
\text { range, } \mathrm{m} \\
\end{array}$ & $\begin{array}{c}\text { Signal } \\
\text { transmission speed }\end{array}$ & $\begin{array}{c}\text { Twisted pair } \\
\text { cable bandwidth }\end{array}$ & $\begin{array}{l}\text { Cable category } \\
\text { according to the } \\
\text { recommendations } \\
\text { of ISO/IEC }\end{array}$ & $\begin{array}{l}\text { Number } \\
\text { of pairs }\end{array}$ \\
\hline 1999 & IEEE 802.3ab & 1000BASE-T & 100 & $1 \mathrm{GBit} / \mathrm{s}$ & $125 \mathrm{MHz}$ & Category $5 \mathrm{e}$ & 4 \\
\hline 2006 & IEEE 802.3an & 10GBASE-T & 55 & $10 \mathrm{GBit} / \mathrm{s}$ & $250 \mathrm{MHz}$ & Category 6 & 4 \\
\hline 2006 & IEEE 802.3an & 10GBASE-T & 100 & $10 \mathrm{GBit} / \mathrm{s}$ & $500 \mathrm{MHz}$ & Category 6 & 4 \\
\hline 2006 & IEEE 802.3an & 10GBASE-T & 100 & $10 \mathrm{GBit} / \mathrm{s}$ & $600 \mathrm{MHz}$ & Category 7 & 4 \\
\hline 2006 & IEEE 802.3an & 10GBASE-T & 100 & $10 \mathrm{GBit} / \mathrm{s}$ & $1000 \mathrm{MHz}$ & Category $7 \mathrm{a}$ & 4 \\
\hline 2015 & IEEE $802.3 \mathrm{bw}$ & 100BASE-T1 & $15 \mathrm{~m} \mathrm{UTP}$ & $100 \mathrm{MBit} / \mathrm{s}$ & $66 \mathrm{MHz}$ & SPE & 1 \\
\hline 2016 & IEEE 802.3 bp & 1000BASE-T1 & $\begin{array}{c}40 \\
15 \mathrm{~m} \mathrm{UTP}\end{array}$ & $1000 \mathrm{MBit} / \mathrm{s}$ & $600 \mathrm{MHz}$ & SPE & 1 \\
\hline 2019 & IEEE $802.3 \mathrm{cg}$ & $\begin{array}{l}\text { 10BASE-T1L } \\
\text { 10BASE-T1S }\end{array}$ & $\begin{array}{c}1000 \\
25 \mathrm{~m} \mathrm{UTP} \\
\end{array}$ & $10 \mathrm{MBit} / \mathrm{s}$ & $20 \mathrm{MHz}$ & SPE & 1 \\
\hline 2020 & IEEE $802.3 \mathrm{ch}$ & Multi-Gig & $(15 \mathrm{~m})$ & $(2.5 / 5 / / 10 \mathrm{GBit} / \mathrm{s})$ & - & SPE & 1 \\
\hline
\end{tabular}

The 10BASE-T1L Standard supports two signal amplitude modes: $2.4 \mathrm{~V}$ for cable lengths up to $1000 \mathrm{~m}$ and $1 \mathrm{~V}$ at a shorter distance. The $1 \mathrm{~V}$ full amplitude mode means that this new physical-level technology can also be used in Ex-proof systems, following strict rules to limit maximum energy. Most importantly, the 10BASET1L Standard provides long-distance transmission thanks to two-wire technology with power supply and data on one cable in the form of twisted pair and belongs to the family of environments with single-pair Ethernet (SPE) (Table 2).

It should be noted that the enterprises of the cable industry of Ukraine do not produce cables for industrial networks. The suppliers of such cables to Ukraine for industrial automation and control are the world's leading companies, in particular, ABB, Siemens, Belden, Helucable [7].

The development of innovative cable products by Ukrainian enterprises requires solving the problem of synthesis of design and technological solutions to establish the production of cables for industrial networks with the appropriate set of electrical parameters.

The goal of the paper is the synthesis of constructive and technological solutions for regulating the electrical capacitance of an insulated conductor at the stage of manufacturing twisted pair cables of industrial networks.

Problem definition. The transmission range and bandwidth of signals in the cable depends on the design and technological solutions that determine the attenuation coefficient, which is determined by the active resistance of conductors $R$, inductance $L$, working capacitance $C_{p}$, active insulation conductivity $G$ (dielectric loss tangent $\operatorname{tg} \delta$ ) [8].

In the high-frequency range, the attenuation coefficient has two components: losses in the metal (conductor) $\alpha_{m}$ and losses in the dielectric (insulation) $\alpha_{d}$

$$
\begin{aligned}
& \alpha=8.69 \cdot\left(\frac{R}{2} \sqrt{\frac{C_{p}}{L}}+\frac{G}{2} \sqrt{\frac{L}{C_{p}}}\right)= \\
& =8.69 \cdot\left(\frac{R}{2} \sqrt{\frac{C_{p}}{L}}+\frac{\omega C_{p} \operatorname{tg} \delta}{2} \sqrt{\frac{L}{C_{p}}}\right)= \\
& =8.69 \sqrt{C_{p}}\left(\frac{R}{2} \sqrt{\frac{1}{L}}+\frac{\omega \operatorname{tg} \delta}{2} \sqrt{L}\right)=\alpha_{m}+\alpha_{d}, d B / m,
\end{aligned}
$$

where

$$
\alpha_{m}=8.69 \sqrt{C_{p}} \frac{R}{2} \sqrt{\frac{1}{L}}, \quad \alpha_{d}=8.69 \sqrt{C_{p}} \cdot \frac{\omega \operatorname{tg} \delta}{2} \sqrt{L}
$$

The working capacitance of the twisted pair (Fig. 1), the conductors of which are twisted with the corresponding step $h$, determines the losses in the conductors and in the insulation (see (2)).

$$
C_{p}=\chi \cdot \frac{\pi \cdot \varepsilon_{0} \cdot \varepsilon}{\ln \left(\frac{a-r}{r} \cdot \psi\right)}, \quad F / m,
$$

where $\chi$ is the twist coefficient of pair conductors to reduce electromagnetic influences, $\psi$ is the coefficient that takes into account the effect on the working capacitance of adjacent pairs and the metal screen, $a$ is the distance between conductors determined by the radius $r_{1}$ of the conductor (1) and insulation thickness $\Delta_{1}(2), \varepsilon$ is the dielectric constant of the insulation (Fig. 1). 
The working capacitance of unshielded and shielded twisted pairs is determined based on the calculation of the electric field [9-13]. For example, in [11] the working capacitance of unshielded twisted pair is determined on the basis of the application of the method of conformal mappings and finite elements in the ELCUT environment. In $[12,13]$ the working capacitance and the influence of the thickness of the layers of three-layer polyethylene insulation on the working capacitance of the shielded twisted pair of category 7 were determined by the method of secondary charges.

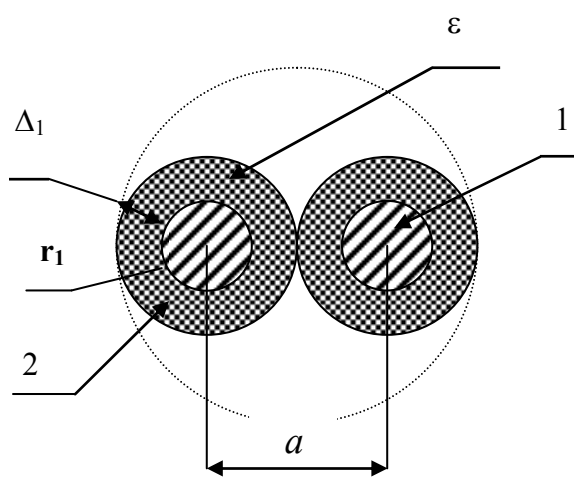

Fig. 1. Twisted pair design

At the technological stage of manufacturing an insulated conductor, as the main structural element of twisted pair, the electrical capacitance is measured. The conductor is a capacitor, one of the covers of which is a metal core of the wire, and the other one is water that cools after applying the insulation, which is in electrical contact with the tubular electrode, through which the controlled insulated conductor moves continuously. This method of control is implemented in the development of leading companies specializing in the production of control devices for the cable industry: Sikora, Zumbach (Table 3) [14, 15]. Electronic units of the measuring system are equipped with modern data ports for connection to display processors or to the main computer (local computer network) by means of industrial interfaces (cables) Profibus DP, Rs-232, -432, -485 [1].

Table 3

Technical characteristics of measuring systems of electric capacitance of cables at technological stage [14, 15]

\begin{tabular}{|c|c|c|c|c|}
\hline Company & Device type & $\begin{array}{c}\text { Range of } \\
\text { diameters, } \\
\mathrm{mm}\end{array}$ & $\begin{array}{c}\text { Range of } \\
\text { capacitance } \\
\text { values, } \\
\mathrm{pF} / \mathrm{m}\end{array}$ & $\begin{array}{c}\text { Accuracy, } \\
\mathrm{pF} / \mathrm{m}\end{array}$ \\
\hline Sikora & $\begin{array}{c}\text { Capacitance } \\
2010\end{array}$ & $0.5-10$ & $0-300$ & \pm 0.45 \\
\cline { 2 - 5 } & $\begin{array}{c}\text { Capacitance } \\
2025\end{array}$ & $1-25$ & $0-300$ & \pm 0.45 \\
\hline \multirow{2}{*}{ Zumbach } & CAPAC $^{\circledR}$ & - & $\begin{array}{c}0-300 \\
0-600\end{array}$ & \pm 0.1 \\
$\pm 0.3 \%$
\end{tabular}

Continuous control of the electrical capacitance of the insulated conductor along its entire length allows to make timely decisions on the regulation of the capacitance at the technological stage of manufacture.
Influence of design decisions on the electrical capacitance of an insulated conductor. Based on the application of the method of secondary charges [12, 13], the electrical capacitance of the insulated conductor is determined by varying the thickness of solid and foamed polyethylene insulation, the environment in which the conductor is at the technological stage of manufacture.

Figure 2 shows the results of calculations of the electrical capacitance of an insulated conductor with constant diameter $r_{l}$ of the conductor and varying the thickness $\Delta_{1}$ of solid insulation for two cases: when in air (curve 1) and in water (curve 2). The dielectric permittivity of the technical cooling water is assumed to be equal to 100 [13].

Figure 2, $a$ shows the absolute values of capacitance, Fig. 2, $b$ - relative values regarding the calculated capacitance in the case $r_{1}=\Delta_{1}$. At this scale, the capacitance calculations coincide for the three values of the conductor diameters $2 r_{1}=0.511 ; 0.57$ and $0.64 \mathrm{~mm}$. Curve 1 refers to the case of cooling the insulated conductor in air, curve 2 - in water.

When cooling in water, the electrical capacitance of the insulated conductor changes more than 2 times, with air cooling - no more than $5 \%$ when varying the thickness of the solid insulation (compare curves 1 and 2, Fig. 2,a,b).

Increasing the insulation thickness by $50 \%$ relative to the radius of the conductor (curve 2, Fig. 2,a,b) leads to a decrease in the capacitance of the insulated conductor by $20 \%$. Such a constructive solution causes growth of mass and dimensions of the twisted pair as a whole. A more effective design and technological solution is the use of foam insulation [12].

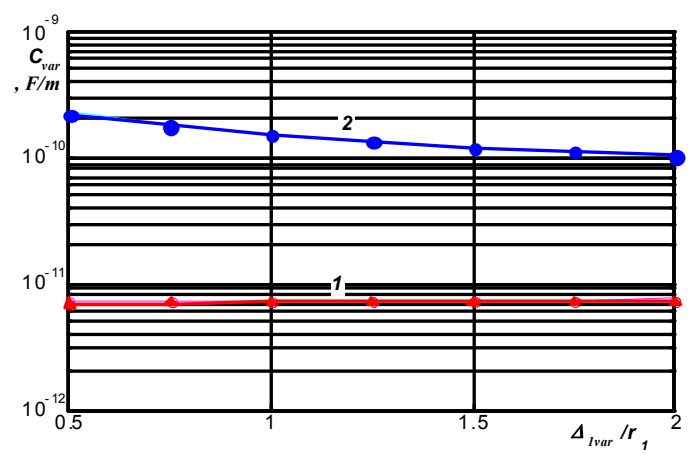

$a$

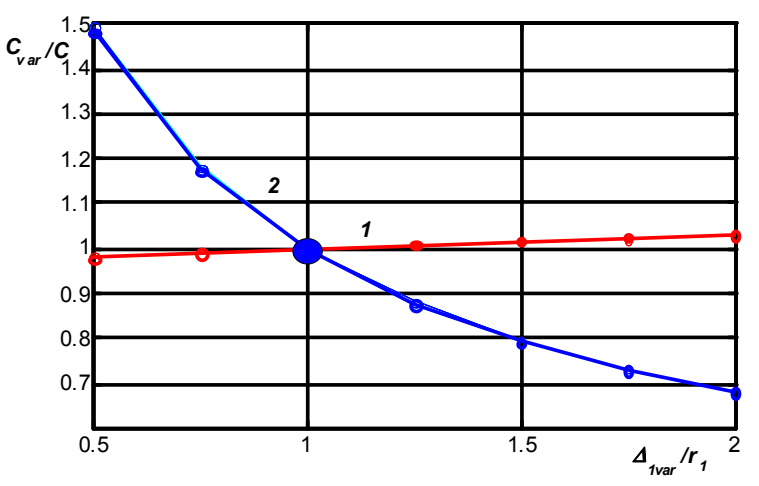

$b$

Fig. 2. Influence of solid insulation thickness on electrical capacitance of insulated conductor in air (curve 1) and water (curve 2) 
Foaming insulation as an effective solution for capacitance regulation. Insulation foaming technology has recently become widely used, including in twisted pairs [12, 16-17]. The most well-known chemical foaming agent is azodicarbonamide, an exothermic chemical foaming agent. It releases a large amount of nitrogen gas into the polymer together with a smaller amount of carbon dioxide.

To calculate the effective dielectric permittivity of foam insulation, which is a statistical mixture (chaotic, disordered in space), the Lichtenecker formula [18] is used - the logarithmic law of mixing.

For a foamed mixture of two components of solid insulation based on polyethylene filled with a large number of small gas pores, the dielectric constant of which is equal to $\varepsilon=1$, the effective dielectric permittivity $\varepsilon_{\text {foam }}$ is determined by the dielectric permittivity of solid polyethylene $\varepsilon_{P E}$ and the ratio of the density of foamed $\rho_{\text {foam }}$ and solid $\rho_{P E}$ insulation, respectively

$$
\lg \varepsilon_{\text {foam }}=\frac{\rho_{\text {foam }}}{\rho_{P E}} \lg \varepsilon_{P E} .
$$

Figure 3 shows the dependence of the effective dielectric permittivity of foamed polyethylene insulation, the tangent of the angle of dielectric loss and the electrical capacitance of the insulated conductor on the value inverse to the degree of porosity $\frac{1}{p_{\text {foam }}}=\frac{\rho_{P E}}{\rho_{\text {foam }}}$.

At the degree of porosity of $40 \%$ (the relative content of solid polyethylene is $60 \%=$ Fig. 3 ), the dielectric permittivity of the mixture decreases in $2 / 1.6=1.25$ times. Accordingly, the tangent of the dielectric loss angle decreases by $33 \%$ and the electrical capacitance of the insulated conductor decreases by $20 \%$, which proves the effectiveness of the use of foam insulation.

The presence of a large number of pores in the solid polyethylene insulation requires a solution to protect the pores from moisture penetration during cable operation. The most attractive is the use of an additional continuous film on the surface of the foam insulation, which acts as a barrier to the penetration of moisture into the foam insulation [12] (Fig. 4).

The influence of the film thickness depending on the degree of porosity of the polyethylene insulation on the effective dielectric permittivity $(a)$, the effective tangent of the dielectric loss angle $(b)$ and the electrical capacitance $(c)$ of the insulated conductor is presented in Fig. 5. Curve 1 in Fig. 5 corresponds to the solid polyethylene insulation, the thickness of which is equal to the radius of the conductor and remains unchanged when foamed $\Delta_{\text {foam }}$. The step of the degree of foaming is equal to 0.05 (curve 11 corresponds to $50 \%$ of the polyethylene content and $50 \%$ of the gas pore content). The thickness of the solid protective film $\Delta_{\text {solad }}$ varies from $0.5 \%$ to $60 \%$ relative to the main insulation.

The use of an additional layer of solid film on the surface of the core to ensure the «rigidity» of the structure with a constant total thickness of insulation leads to an increase in the capacitance of three-layer insulation by no more than $5 \%$ compared to two-layer insulation.
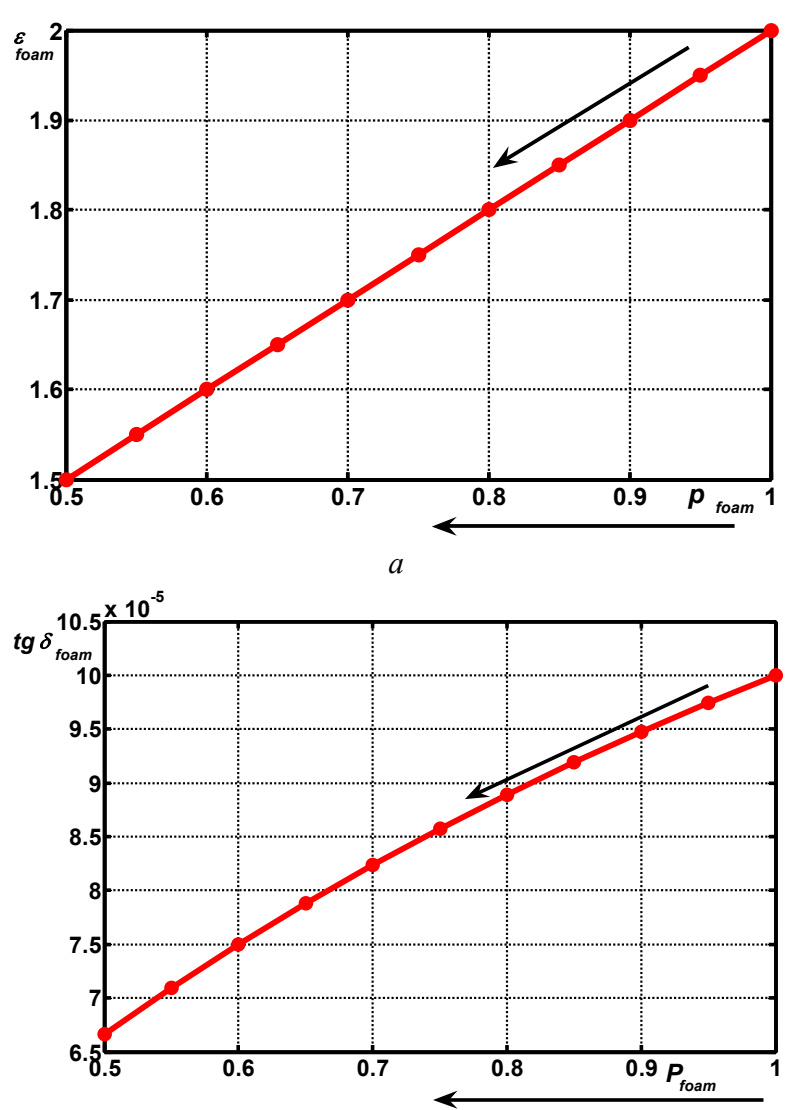

b

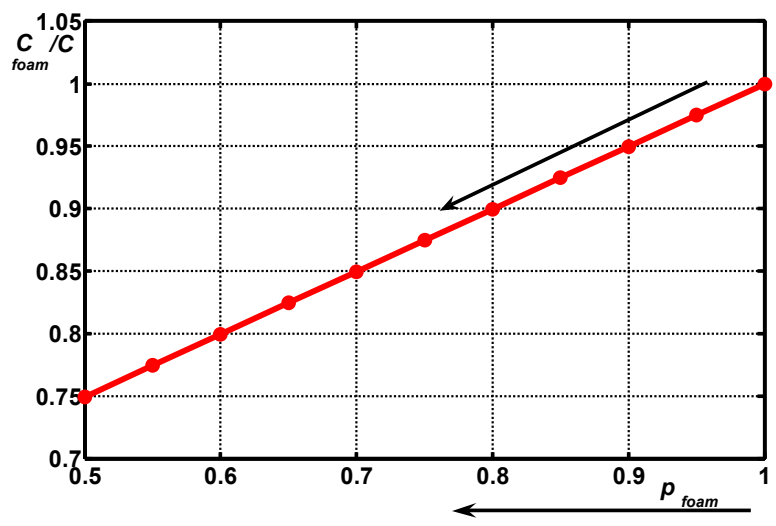

$c$

Fig. 3. The effect of the degree of porosity of polyethylene $p_{\text {foam }}$ on the effective dielectric permittivity $(a)$, effective dielectric loss tangent $(b)$ and electric

capacitance $(c)$ of the insulated conductor

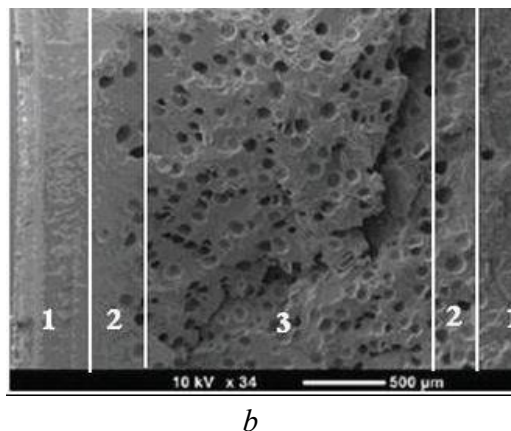

Fig. 4. Structure of foamed polyethylene insulation without protective film $(a)$ and with protective polyethylene film $(b)$ : 1 - film, 2 - transition zone, 3 - proper foam insulation [16] 


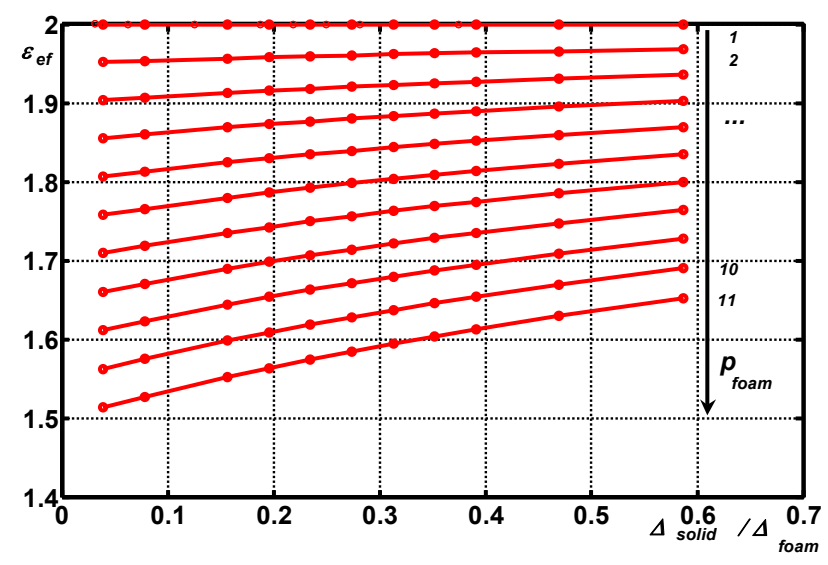

$a$

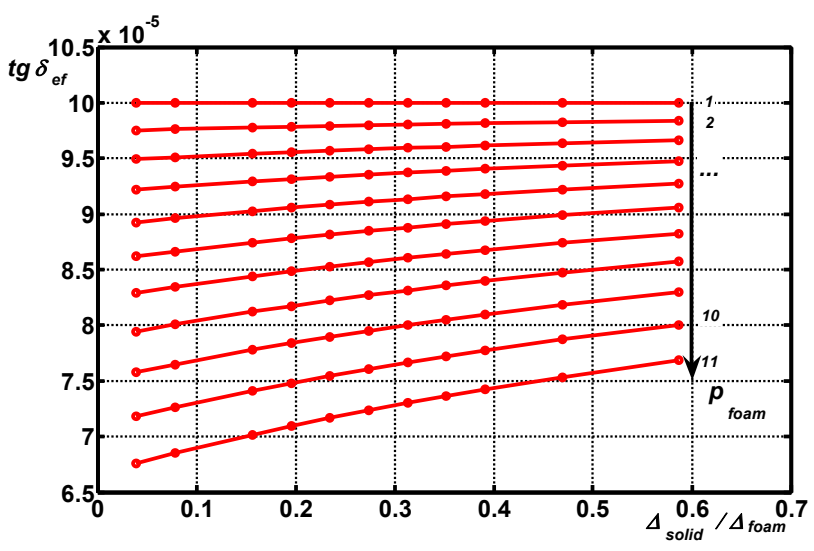

b

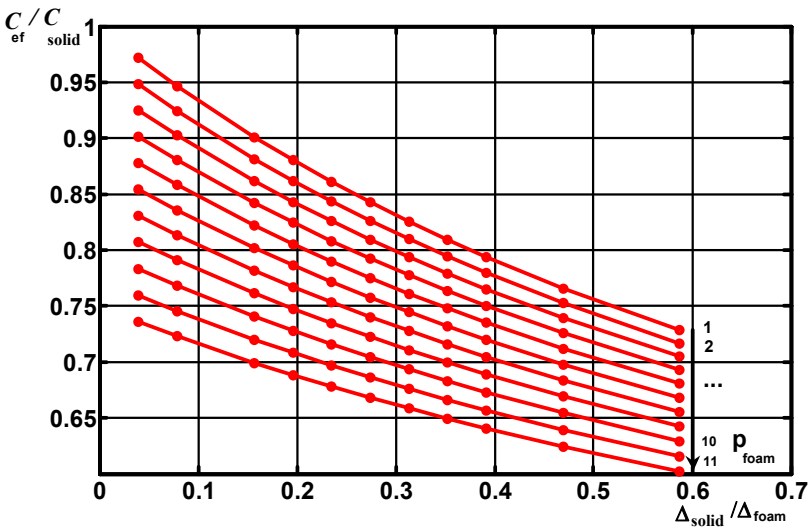

Fig. 5. 3D-diagram of the influence of the degree of porosity of polyethylene and the thickness of the protective solid polyethylene film on the electrophysical characteristics and electrical capacitance of the insulated conductor

\section{Conclusions.}

The location of the insulated conductor in the cooling water provides a high sensitivity to the settings of the technological process for regulation of the capacitance when varying the thickness of the insulation. When the insulation thickness changes 4 times relative to the diameter of the conductor, the electrical capacitance changes more than 2 times. When in the air - by $5 \%$.

For the first time, nomograms of effective dielectric permitivity, dielectric loss angle tangent and relative capacitance values depending on the degree of foaming of solid polyethylene insulation and protective film thickness are obtained, which allow to effectively regulate the electrical capacitance of twisted pair conductor insulation.

The methodology of synthesis of constructivetechnological solutions for regulating the capacitance of twisted pair cables of industrial networks at the technological stage of manufacturing an insulated conductor is substantiated.

The developed technique can be used to adjust the technological process of manufacturing insulated conductors of cables for various purposes, including power ones.

Conflict of interests. The authors declare no conflicts of interest.

\section{REFERENCES}

1. Pigan R., Metter M. Automating with PROFINET: Industrial Communication Based on Industrial Ethernet. John Wiley \& Sons Publ., 2015. 462 p.

2. Bezprozvannych G.V., Pushkar O.A. Increasing noise immunity of cables for fire protection systems. Electrical Engineering \& Electromechanics, 2020, no. 4, pp. 54-58. doi: https://doi.org/10.20998/2074-272x.2020.4.07.

3. Belous A., Saladukha V. High-Speed Digital System Design: Art, Science and Experience. Springer Nature Publ., 2019. 933 p.

4. International Standard ISO/IEC 11801. Information Technology - Generic cabling for customer premises. Part 2: Office premises. 2017. 24 p.

5. Semenov A. Advanced Twisted Pair Cables for Distributed Local Area Networks in Intelligent Structure Systems. IOP Conference Series: Materials Science and Engineering, 2018, vol. 317, p. 012053. doi: https://doi.org/10.1088/1757899x/317/1/012053.

6. Penttinen Jyrki T.J. The Telecommunications Handbook: Engineering Guidelines for Fixed, Mobile and Satellite Systems. John Wiley \& Sons Publ., 2015. 1008 p.

7. Sending all the right signals. White paper. Single pair Ethernet in the Industrial Field. Belden, 2020. 8 p.

8. Bezprozvannych G.V., Ignatenko A.G. Optimization of the design of network cables by the attenuation coefficient in the tolerance zone of the geometric dimensions of the transmission parameters. Electrical Engineering \& Electromechanics, 2004, no. 2. pp. 8-10. (Rus).

9. Iossel Yu.Ya., Kochanov E.S., Strunsky M.G. Raschet elektricheskoi emkosti [Calculation of electrical capacity]. Leningrad, Energoizdat Publ., 1981. 288 p. (Rus).

10. Levin B.M. Calculation of Electrical Parameters of TwoWire Lines in Multiconductor Cables. IEEE Transactions on Electromagnetic Compatibility, 2008, vol. 50, no. 3, pp. 697703. doi: https://doi.org/10.1109/temc.2008.927924.

11. Vishnyakov E.M., Khvostov D.V. Calculation of inter-wire inductance and capacitance of symmetric straight pairs by methods of conformal mappings and finite elements. Cablenews, 2007, no. 3 (13), pp. 30-36. (Rus).

12. Boyko AM, Bezprozvannych G.V. Justification of insulation thickness of twisted shielded pairs of structured cable systems. Bulletin of NTU «KhPI», 2011, no. 3, pp. 21-35. (Ukr).

13. Bezprozvannych G.V. Comparative analysis of the transverse structure of unfilled and filled telephone cables based on capacity and dielectric dissipation measurement results. Electrical Engineering \& Electromechanics, 2007, no. 5, pp. 6166. (Rus). 
14. Sikora Technology to Perfection / Capacitance 2000. Available at: https://sikora.net/en/products/capacitance2000/ (Accessed 14.09.2020).

15. Zumbach Electronics. CAPAC® / FFT / SRL Overview. Available at: https://www.zumbach.com/ru/products/product-finder/capacfft-srl/capac-overview.html (Accessed 14.09.2020).

16. Xu Z., Xue P., Zhu F., He J. Effects of formulations and processing parameters on foam morphologies in the direct extrusion foaming of polypropylene using a single-screw extruder. Journal of Cellular Plastics, 2005, vol. 41, no. 2, pp. 169-185. doi: https://doi.org/10.1177/0021955x05051740.

17. Pinto J., Notario B., Verdejo R., Dumon M., Costeux S., Rodriguez-Perez M.A. Molecular confinement of solid and gaseous phases of self-standing bulk nanoporous polymers inducing enhanced and unexpected physical properties. Polymer, 2017, vol. 113, pp. 27-33. doi: https://doi.org/10.1016/j.polymer.2017.02.046.

18. Palchykov O.O. Determination of the effective permittivity of a heterogeneous material. Electrical Engineering \&
Electromechanics, 2020, no. 2, pp. 59-63. doi: https://doi.org/10.20998/2074-272x.2020.2.09.

Received 10.11.2020 Accepted 06.12.2020 Published 25.02.2021

G.V. Bezprozvannych ${ }^{1}$, Doctor of Technical Science, Professor, I.A. Kostiukov ${ }^{1}$, Ph.D., Doctoral Student,

O.A. Pushkar ${ }^{2}$, General Director, Graduate Student,

${ }^{1}$ National Technical University «Kharkiv Polytechnic Institute», 2, Kyrpychova Str., Kharkiv, 61002, Ukraine, e-mail: bezprozvannych@kpi.kharkov.ua, iakostiukow@gmail.com

${ }^{2}$ Company «Alay», 95 A2, office 202, Otradny Ave., Kyiv, 03061, Ukraine, e-mail:adm@alay.com.ua

How to cite this article:

Bezprozvannych G.V., Kostiukov I.A., Pushkar O.A. Synthesis of constructive-technological decisions of regulation of working capacitance of cables of industrial networks. Electrical Engineering \& Electromechanics, 2021, no. 1, pp. 44-49. doi: 10.20998/2074-272X.2021.1.07. 